\title{
Color Shade Heritability of Peach Flesh
}

\author{
Maximiliano Dini ${ }^{1}$, Maria do Carmo B. Raseira ${ }^{2}$, Silvia Scariotto ${ }^{3}$, Bruno Carra ${ }^{1}$, Everton S. de Abreu ${ }^{1}$, \\ Paulo Mello-Farias ${ }^{1} \&$ Rufino F. F. Cantillano ${ }^{4}$ \\ ${ }^{1}$ Programa de Pós-Graduação em Agronomia, Facudade de Agronomia Eliseu Maciel, Universidade Federal de \\ Pelotas, Pelotas, Rio Grande do Sul, Brazil \\ ${ }^{2}$ Fruit Breeding, Embrapa Clima Temperado, Pelotas, Rio Grande do Sul, Brazil \\ ${ }^{3}$ Universidade Tecnológica Federal do Paraná, Pato Branco, Paraná, Brazil \\ ${ }^{4}$ Postharvest Physiology and Technology, Embrapa Clima Temperado, Pelotas, Rio Grande do Sul, Brazil \\ Correspondence: Maximiliano Dini, Programa de Pós-Graduação em Agronomia (PPGA), Facudade de \\ Agronomia Eliseu Maciel (FAEM), Universidade Federal de Pelotas (UFPel), Campus Capão do Leão, s/n, \\ 96160-000, Rio Grande do Sul, Brazil. Tel: 55-51-996-381-893. E-mail: maxidini@hotmail.com
}

Received: March 21, 2019

Accepted: April 28, 2019 Online Published: June 15, 2019

doi:10.5539/jas.v11n8p236

URL: https://doi.org/10.5539/jas.v11n8p236

This research was partially financed by the Agencia Nacional de Investigación e Innovación-Uruguay (ANII) in the first year and by the Coordenação de Aperfeiçoamento de Pessoal de Nivel Superior-Brazil (CAPES) in the second year.

\begin{abstract}
Nowadays, despite of being a typically temperate fruit crop, peach is found in subtropical and even tropical altitude zones, due to breeding efforts. Genetic knowledge and phenotypic and environmental parameters directly or indirectly influence the characters of economic importance in peach, and they are of great importance for breeding programs orientation. The aim of this study was to estimate heritability of a color shade character of peach flesh, measured by the Hue angle, chroma and lightness to evaluate its distribution in the populations, testing the possible existence of maternal effect. Results showed that parameters related to color shade of peach flesh have a medium heritability. Parents selection based on phenotype allows a medium genetic improvement for the mentioned character. This heritability is predominantly additive, without maternal effect. The Hue angle is the correct parameter to be used to classify and study yellow-flesh peaches and nectarines in relation to their color shade. However, the multivariate analysis of principal components, using the three parameters Hue angle, chroma and lightness, is an alternative of high accuracy.
\end{abstract}

Keywords: Prunus persica (L.) Batsch, maternal heritability, progeny segregation

\section{Introduction}

Fruit quality attributes are determinant for consumer acceptance and market value, being the flesh color a primary component (Williamson et al., 2006). Generally, in fruit commercialization, cultivars are classified in white or yellow-flesh peaches and nectarines (Adami et al., 2013; Raseira et al., 2014). However, several shades can be found inside those of white-flesh as white-green, white and white-cream; and inside those of yellow-flesh as light-yellow, yellow, yellow-orange and orange (Byrne et al., 2012; Castro \& Barbieri, 2014; Raseira \& Franzon, 2014). There is a third less known phenotypic group with red flesh ("Red blood flesh"), which has a dominant inheritance character, regardless if the background color is white or yellow (Werner et al., 1998; Bassi $\&$ Monet, 2008).

Carotenoids (orange pigments) and xantophylls (yellow pigments) give color to the flesh, both are located in the chloroplasts (chromoplasts) and found in greater quantity in yellow fruits as compared to white fruits. Among the carotenoids, the most common are $\beta$-carotene and $\beta$-cryptoxanthin, which are the primary factors of pro-vitamin A (Tourjee et al., 1998; Gil et al., 2002; Bassi \& Monet, 2008). Yellow-flesh cultivars show a $\beta$-carotene content between 2 and $3 \mathrm{mg}$ per $100 \mathrm{~g}$ of fresh mass, whereas white-flesh cultivars present amounts up to 10 times smaller, varying from $0.01 \mathrm{mg}$ to $1.8 \mathrm{mg}$ per $100 \mathrm{~g}$ of fresh mass (Vizzotto et al., 2006; Adami et al., 2013). 
Color flesh is a simple Mendelian inheritance trait controlled by a single gene pair, with white $(Y)$ dominant in relation to yellow $(y)$ (Connors, 1920). However, differences in the shades between yellow or white genotypes may be due to a more complex control, by locus $Y$, acting on other loci, and/or maternal effect (Williamson et al., 2006; Raseira \& Franzon, 2014).

The communication of color perception in scientific experiments implies not only the evaluation and description of colors by an individual, but also the interpretation by another person of the described colors. Color Charts have played an intermediate role in this process for a long time, and the Royal Horticultural Society (RHS) recommends Color Charts, being the standard reference used by horticulturists worldwide. However, visual color assessment is often defective. The increased availability of portable color measurement instruments has made possible a more objective assessment (Voss, 1992).

Although peache's flesh color shade has little relevance for fresh fruit market, it is very important for the Brazilian canning industry, due to the variability on yellow shade of flesh of the cultivars used for this purpose. A negative factor for the compote quality that is found in the same package (can or glass) is fruits of light-yellow flesh, together with fruits of orange flesh (Raseira et al., 2014).

In order to estimate the color shade of peach flesh heritability, Corrêa (2007) concluded that, for detailed studies, as an inheritance, Color Charts use is not efficient, and recommended the use of colorimeter and the Hue angle value for calculation. The same researcher observed a higher frequency of individuals with similar tonality to the female parent, suggesting a possible maternal effect.

The aim of this study was to estimate the heritability of the color shade character of peach flesh, measured by the Hue angle, chroma and lightness, in the broad and narrow-sense. Moreover, it is to evaluate its distribution in the populations, testing the possible existence of maternal effect in the character inheritance.

\section{Method}

\subsection{Plant Material}

The study was developed in the Fruit Breeding Laboratory and Post-Harvest Laboratory of Embrapa Temperate Agriculture, Pelotas, Rio Grande do Sul, Brazil (31 ${ }^{\circ} 40^{\prime} \mathrm{S}, 52^{\circ} 26^{\prime} \mathrm{W}$, alt $57 \mathrm{~m}$ asl.), during 2015-2016 and 2016-2017 cycles. Seedlings ( $F_{1}$ progenies) derived from hybridizations, as well as their parents, were described in Table 1.

Table 1. Parents of F1 progenies studied, flesh color and number of seedlings of each progeny, in the Peach Breeding Program at Embrapa Temperate Agriculture, Pelotas, Rio Grande do Sul, Brazil

\begin{tabular}{|c|c|c|c|}
\hline \multirow{2}{*}{$\mathrm{F}_{1}$ progeny } & \multicolumn{2}{|c|}{ Parents } & \multirow{2}{*}{$\mathrm{N}^{\circ}$ seedlings } \\
\hline & q & $\hat{\sigma}$ & \\
\hline $2008.159 *$ & Conserva 1526 (CP; Yellow-flesh) & 'Cerrito' (CP; Yellow-flesh) & 7 \\
\hline 2009.38 & 'Cerrito' & Conserva 1526 & 23 \\
\hline 2012.26 & Cascata 1055 (FMP; White-flesh) & 'Chimarrita' (FMP; White-flesh) & 18 \\
\hline 2012.43 & 'Chimarrita' & Cascata 1055 & 25 \\
\hline 2012.49 & Conserva 672 (CP; Yellow-flesh) & Conserva 1526 (CP; Yellow-flesh) & 18 \\
\hline 2012.61 & Conserva 1526 & Conserva 672 & 7 \\
\hline 2012.52 & Conserva 947 (CP; Yellow-flesh) & Conserva 1600 (CP; Yellow-flesh) & 17 \\
\hline 2012.66 & Conserva 1600 & Conserva 947 & 12 \\
\hline 2012.68 & Conserva 1662 (CP; Yellow-flesh) & 'Maciel' (CP and FMP; Yellow-flesh) & 24 \\
\hline 2012.88 & 'Maciel' & Conserva 1662 & 17 \\
\hline 2012.31 & Cascata 1359 (FMP; Yellow-flesh) & Cascata 1577 (FMP; White-flesh) & 31 \\
\hline 2012.46 & 'Chorão' (FMP; White-flesh) & 'Maciel' (CP and FMP; Yellow-flesh) & 25 \\
\hline 2012.99 & Necta 506 (Yellow-flesh nectarine) & 'Sunmist' (White-flesh nectarine) & 20 \\
\hline 2012.107 & Necta 532 (Yellow-flesh nectarine) & Necta 480 (Yellow-flesh nectarine) & 25 \\
\hline 2012.111 & Necta 540 (Yellow-flesh nectarine) & 'Morena' (Yellow-flesh nectarine) & 25 \\
\hline 2012.114 & 'BRS Rubimel' (FMP; Yellow-flesh) & TX2D163 (FMP; Yellow-flesh) & 21 \\
\hline
\end{tabular}

Note. * Internal progeny identification at Embrapa; $\mathrm{CP}=$ Canning peach; FMP $=$ Fresh market peach. 
Parents were represented by three plants (clones obtained by grafting), and from each plant, five fruits were harvested and evaluated, totaling fifteen fruits in each evaluated cycle. Samples of five fruits per seedling were used for progeny individuals.

\subsection{Colorimeter, Hue Angle, Chroma and Lightness}

Fruits were harvested at commercial maturation stage in the four quadrants of the plant, at similar heights, being the epidermis background color and flesh firmness the main factors to determine harvest. After that, fruits were taken to the post-harvest laboratory, where two cuts were made on the flesh in mid-depth between the epidermis and the stone, one on each side of the fruit and perpendicular to the suture. Fruit color shade of flesh was measured with the Minolta CR-300 electronic colorimeter, with D65 light source and $8 \mathrm{~mm}$ aperture.

The colorimeter used performs the readings in the CIELAB color measurement system or CIE $1976 L^{*} a^{*} b^{*}$, in which, the $L^{*}$ coordinate is the lightness and expresses the degree of lightness of the measured color $(100=$ white; 0 = black). The $a^{*}$ coordinate expresses the degree of variation between green and red, being associated with peach fruits ripening (Byrne et al., 1991), and the $b^{*}$ coordinate expresses the degree of variation between blue and yellow (Trevisan et al., 2004; Silva, 2013). The $a^{*}$ and $b^{*}$ values are not independent variables, so they are not analyzed directly (CIE, 2007); however, they are used to calculate the Hue angle $\left(h_{a b}\right)$ or color angle (CIE, 2007; Trevisan et al., 2004; Voss, 1992), and the chroma $\left(C^{*}{ }_{a b}\right)$ or color saturation (Voss, 1992; Bible \& Singha, 1993; CIE, 2007). The $h_{a b}$ is the angle between the hypotenuse and $0^{\circ}$ on $a^{*}$ axis and expresses the color tones. For the interpretation, the results are expressed in degrees and vary from 0 to $360^{\circ}$, initiating the opening in the $+a^{*}$ axis $=0^{\circ}$ (red color); $90^{\circ}+b^{*}$ (yellow); $180^{\circ}-a^{*}$ (green) and $270^{\circ}-b^{*}$ (blue) (Figures 1a and $1 \mathrm{~b}$ ).
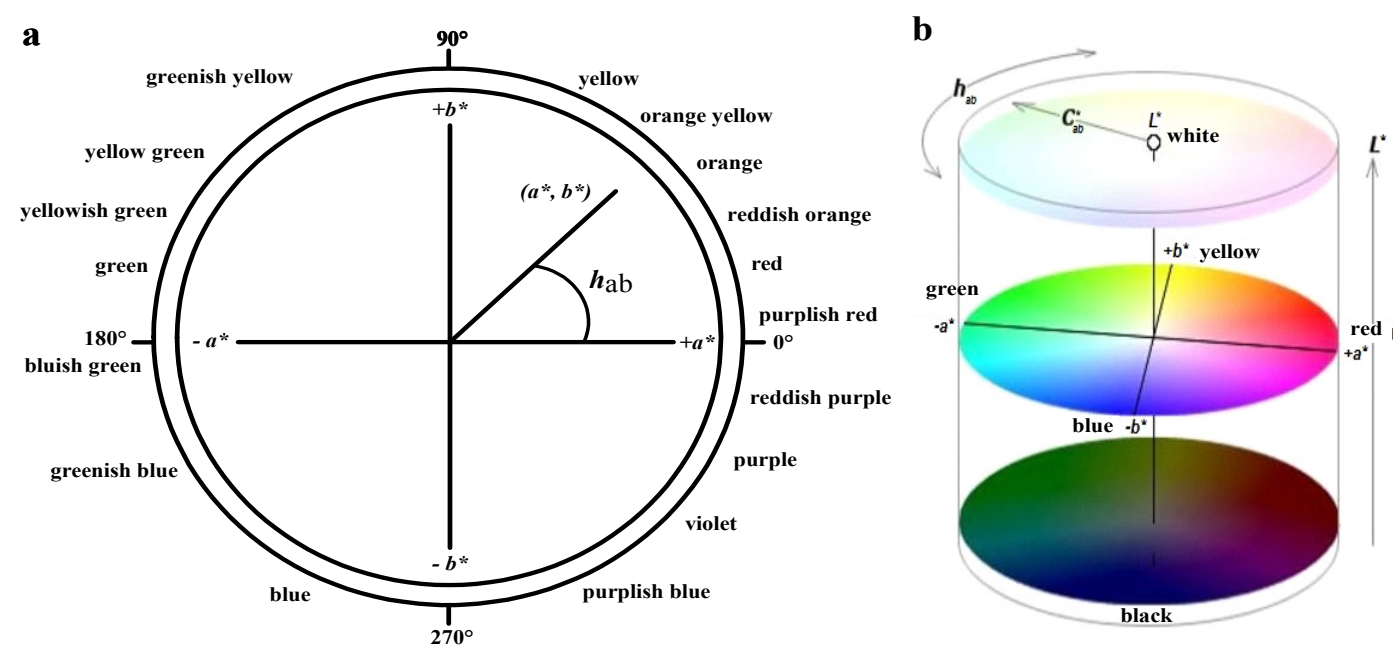

Figure 1. (a) Diagram with the sequence of colors according to Hue angle (adapted from Voss, 1992; Chitarra \& Chitarra, 2005). (b) Geometry of the CIELAB color model (adapted from Macevoy, 2005). $a^{*}$ and $b^{*}=$ CIELAB coordinates; $-a^{*}=$ green; $+a^{*}=$ red; $-b^{*}=$ blue; $+b^{*}=$ yellow; $h_{a b}=$ Hue angle; $C^{*}{ }_{a b}=$ chroma; $L^{*}=$ lightness

Hue angle is calculated with the following formula (Voss, 1992; CIE, 2007):

$$
h_{a b}=\operatorname{tang}^{-1}\left(b^{*} / a^{*}\right)
$$

and chroma, with (Voss, 1992; Bible \& Singha, 1993; CIE, 2007):

$$
C^{*} a b=\left(a^{*^{2}}+b^{* 2}\right)^{1 / 2}
$$

The $h_{a b}, C^{*}{ }_{a b}$ and $L^{*}$ values were used in this research analysis.

\subsection{Heritability Estimation}

Broad-sense heritability $\left(\mathrm{H}^{2}\right)$ was estimated for the parameters referring to the color shade of peach flesh $\left(h_{a b}\right.$, $C^{*}{ }_{a b}$ and $L^{*}$ ). The mean variance observed among clones was considered as the mean environmental variance $\left(\sigma_{\mathrm{e}}{ }^{2}\right)$. The variance observed among individuals belonging to the same progeny was used as the total phenotypic variance $\left(\sigma_{\mathrm{p}}^{2}\right)$, (genetic effect + environmental). The genetic variance $\left(\sigma_{\mathrm{g}}{ }^{2}\right)$ was calculated by subtracting the environmental variance from the total variance of each progeny (Wagner Júnior, 2003; Côrrea, 2007). Finally, 
the calculation of the $\mathrm{H}^{2}$ was estimated by dividing the genetic variance by the total variance (Allard, 1960; Griffiths et al., 2015):

$$
H^{2}=\sigma_{g}^{2} /\left(\sigma_{g}^{2}+\sigma_{e}^{2}\right)
$$

Narrow-sense heritability $\left(\mathrm{h}^{2}\right)$ was estimated from the regression of the average of parental phenotypic values versus the means of offspring phenotypic values (Griffiths et al., 2015). The $\mathrm{h}^{2}$ estimated value corresponds to the regression coefficient "b" of the equation of the line below (Falconer \& Mackay, 2001; Griffiths et al., 2015):

$$
Y=a+b x
$$

\subsubsection{Maternal Effect and Frequency Distributions}

The maternal effect was evaluated by comparing the progeny of one of the crosses with the progeny of their reciprocal crossing $\left(\mathrm{F}_{1}\right.$ vs. reciprocal $\mathrm{F}_{1}$ ), by $t$-test at $5 \%$ significance (Londero et al., 2009) for the studied parameters $\left(h_{a b}, C^{*}{ }_{a b}\right.$ and $\left.L^{*}\right)$.

Frequency distributions and their histograms were calculated with color shade data. The yellow flesh individuals were classified into the following flesh color categories: greenish-yellow, light-yellow, yellow, yellow-orange and orange (Castro \& Barbieri, 2014); whereas the white-flesh ones were: white-green, white and white-cream or white with red spots (Castro \& Barbieri, 2014; Raseira \& Franzon, 2014). The limits of these colors were defined by $h_{a b}$ values, in agreement with the diagrams proposed by Voss (1992), Chitarra and Chitarra (2005) and Adriano et al. (2011).

\subsubsection{Multivariate Analysis}

A multivariate analysis was performed using a methodology of principal components with the three variables $\left(h_{a b}, C^{*}{ }_{a b}\right.$ and $L^{*}$ ), identifying groups of individuals according to the classification previously proposed.

\section{Results and Discussion}

High variability was detected for $h_{a b}$, which was indicated by the interval 62.17 to $100.79^{\circ}$, with an average of $87.13 \pm 5.34^{\circ}$ and phenotypic variance of 28.47 among progenies of yellow-flesh individuals. However, for white-flesh seedlings, the interval was 44.17 to $112.43^{\circ}$, with an average of $98.67 \pm 10.28^{\circ}$ and phenotypic variance of 105.78 (Table 2). For this same parameter, the parents used ranged from 74.15 to $101.63^{\circ}$ for those of yellow-flesh and from 89.30 to 111.41 for those of white-flesh.

The descriptive parameters for $h_{a b}$ in the yellow-flesh fruits presented lower values than those of white-flesh (Table 2), where the majority of individuals with yellow-flesh was classified among the colors of yellow-orange $\left(<85^{\circ}\right)$ and light-yellow flesh $\left(>90^{\circ}\right)$ (Figure 1A). These values obtained for $h_{a b}$ corroborate with those found by Corrêa (2007), who, when analyzing progenies of yellow-flesh peaches, observed $h_{a b}$ values between 75 and $89^{\circ}$. They are also in agreement, but with a wider range, with the average values obtained by Mayer et al. (2008), who studied four genotypes of yellow-flesh peaches and found $h_{a b}$ values between 90 and $100^{\circ}$.

Table 2. Descriptive statistics of coordinates $a^{*}$ and $b^{*}$ and, of the Hue angle $\left(h_{a b}\right)$, chroma $\left(C^{*}{ }_{a b}\right)$ and lightness $\left(L^{*}\right)$ variables, evaluated in 16 peach progenies and their parents, separated in yellow-flesh and white-flesh in the

\begin{tabular}{|c|c|c|c|c|c|c|c|c|c|c|c|}
\hline & & \multicolumn{5}{|c|}{ Yellow-flesh } & \multicolumn{5}{|c|}{ White-flesh } \\
\hline & & $a^{*}$ & $b^{*}$ & $h_{a b}$ & $C_{a b}^{*}$ & $L^{*}$ & $a^{*}$ & $b^{*}$ & $h_{a b}$ & $C_{a b}^{*}$ & $L^{*}$ \\
\hline \multirow{5}{*}{ 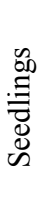 } & Mean & 2.79 & 52.44 & 87.13 & 52.73 & 70.32 & -3.39 & 20.61 & 98.67 & 21.20 & 75.28 \\
\hline & Phenotypic Variance & 23.77 & 17.75 & 28.47 & 18.41 & 15.23 & 14.11 & 19.73 & 105.78 & 20.72 & 11.14 \\
\hline & CV $(\%)$ & 174.93 & 8.04 & 6.12 & 8.14 & 5.55 & 110,96 & 21,56 & 10.42 & 21.47 & 4.43 \\
\hline & Minimum & -8.83 & 39.10 & 62.17 & 40.87 & 37.10 & -11.06 & 12.13 & 44.17 & 13.01 & 60.55 \\
\hline & Maximum & 21.15 & 73.85 & 100.79 & 74.38 & 80.98 & 19.27 & 54.08 & 112.43 & 54.13 & 84.14 \\
\hline \multirow{5}{*}{ 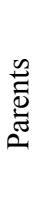 } & Mean & 4.68 & 54.65 & 85.32 & 55.13 & 71.14 & -5.00 & 19.93 & 103.42 & 20.60 & 75.61 \\
\hline & Phenotypic Variance & 32.20 & 19.66 & 33.05 & 21.49 & 13.23 & 4.88 & 15.55 & 19.73 & 18.26 & 6.26 \\
\hline & $\mathrm{CV}(\%)$ & 121.33 & 8.11 & 6.74 & 8.41 & 5.11 & 44.17 & 19.78 & 4.29 & 20.74 & 3.31 \\
\hline & Minimum & -9.50 & 43.64 & 74.15 & 43.80 & 55.51 & -10.61 & 13.11 & 89.30 & 13.42 & 69.42 \\
\hline & Maximum & 18.87 & 66.68 & 101.63 & 69.29 & 79.09 & 0.19 & 31.36 & 111.41 & 32.36 & 80.41 \\
\hline
\end{tabular}
2015-2016 and 2016-2017 cycles, Embrapa Temperate Agriculture, Pelotas, Rio Grande do Sul, Brazil

Note. $a^{*}$ and $b^{*}=$ CIELAB coordinates; $-a^{*}=$ green; $+a^{*}=$ red; $-b^{*}=$ blue; $+b^{*}=$ yellow. 
The highest values were obtained in progenies of white-flesh peaches, with a minimum value of $44.17^{\circ}$ and maximum of $112.43^{\circ}$ (Table 2). Some of these measurements, with very low values for $h_{a b}$, may be due to the presence of spots or traces of reddish colorations, which influence the correct color definition. These reddish colorations are present in the 'Chimarrita' and 'Chorão' parents and in some individuals of their progenies (2012.26, 2012.43 and 2012.46).

High values obtained for $h_{a b}$ corroborate with those found by Silva (2013), who analyzed 116 individuals of yellow and white-flesh, belonging to five progenies and reported $h_{a b}$ values between 44 and $106^{\circ}$. However, the same author did not mention whether these extremes were from yellow or white-flesh fruits.

Chroma or color saturation is the measure that goes from the center of the CIELAB system $\left(C^{*}{ }_{a b}=0=\right.$ gray $)$ to the direction of pure colors $\left(C^{*}{ }_{a b}=100\right)$ (Figure 1B), being that $C^{*}{ }_{a b}$ with higher values indicative of higher purity or color intensity (CIE, 2007). For this parameter, a high variability was also observed and for the evaluated seedlings, intervals between 40.87 and 74.38 (yellow-flesh) and between 13.01 and 54.13 (white-flesh) were obtained (Table 2). For this parameter and in both cases, genotypes with transgressive segregation were registered; in other words, individuals within progenies had more extreme values than the parents.

Lower average values for $C^{*}{ }_{a b}$ were observed in fruits of white-flesh (Table 2), presenting a mean of 21.20 \pm 4.55 for progeny individuals and $20.60 \pm 4.27$ for white-flesh parents. In contrast to the white-flesh fruits, higher $C^{*}{ }_{a b}$ values were found in the yellow-flesh fruits, mean of $52.73 \pm 4.29$, for seedlings, and $55.13 \pm 4.64$ for yellow-flesh parents. This was the expected result, since this character indicates the color intensity, being greater in the genotypes of yellow-flesh (Figure 1B). Similar values were observed by Mayer et al. (2008), when evaluating four genotypes of yellow-flesh peaches, that found $C^{*}{ }_{a b}$ values between 55 and 65 .

$L^{*}$ coordinate within the CIELAB color measurement system expresses the measured color lightness degree $\left(L^{*}\right.$ $=100=$ white; $L^{*}=0=$ black) (Figure 1B). High variability was also detected for this parameter. The mean values with lowest $L^{*}$ were found in yellow-flesh genotypes, and this coordinate ranged from 37.10 to 80.98 (seedlings) and 55.51 to 79.09 (parents). Moreover, the highest $L^{*}$ values were observed in the white-flesh genotypes, ranging from 60.55 to 84.14 (seedlings) and from 69.42 to 80.41 (parents). Studies performed in the same colorimeter model were used to evaluate yellow-flesh peach fruits and reported $L^{*}$ values between 60 and 73 (Tourjee et al., 1998; Mayer et al., 2008). Therefore, it had less range than those found in the present study, perhaps due to a smaller number of studied genotypes.

Progenies, where at least one of the parents was white-flesh (2012.26, 2012.43, 2012.31, 2012.46 and 2012.99), were segregated to both white and yellow-flesh, linked to the parents heterogosity. However, this fact was not considered during the estimated heritability calculation neither for the subsequent studies, given its monogenic condition (Connors, 1920), and the fact that the research interest focused on the different flesh color tonalities of fruits.

$\mathrm{H}^{2}$ for Hue angle parameter was estimated as $77.40 \%$, among all the evaluated progenies with yellow-flesh parents. It should be noted that only one progeny originated from hybridization of two white-flesh parents. This heritability value was lower than the estimate found by Corrêa (2007), which was $90 \%$, when having a colorimeter to perform the measurements. The same author used color charts of the Royal Horticultural Society in some color measurements, and the $\mathrm{H}^{2}$ estimate in this case was $25 \%$, concluding that, for detailed studies of inheritance of this character, the use of color charts was not efficient.

The $\mathrm{h}^{2}$ for $h_{a b}$ was $60.41 \%$, by the linear regression between the $h_{a b}$ mean values of parents (midparent) and the mean values of progenies (mean of offspring) of yellow-flesh (Figure 2a). 

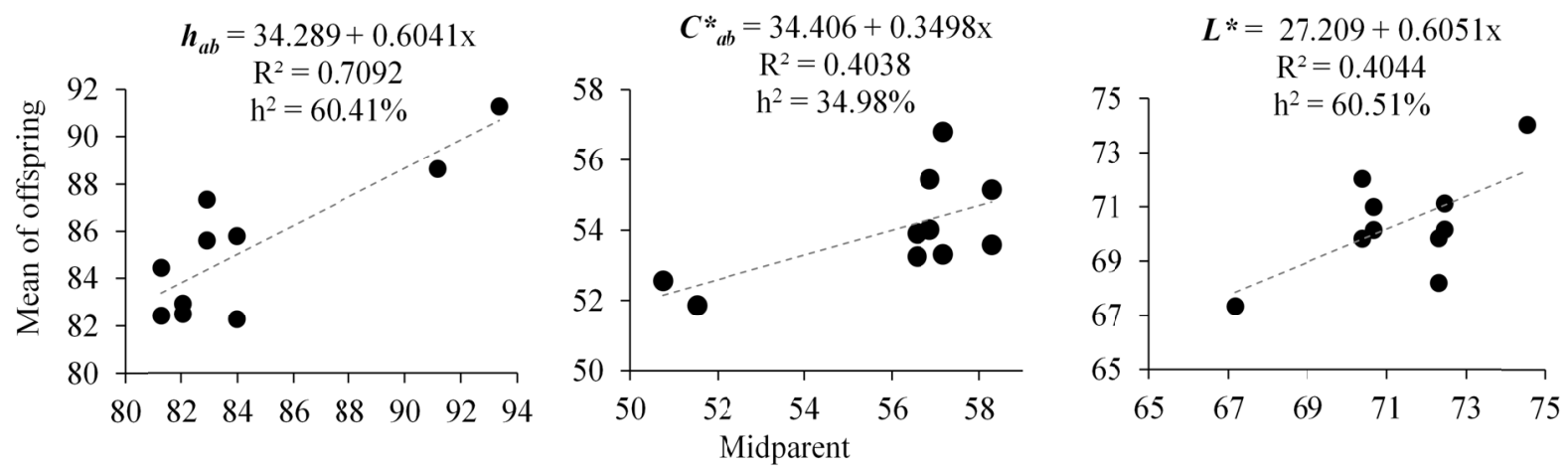

Figure 2. Narrow-sense heritability $\left(\mathrm{h}^{2}\right)$ for (a) Hue angle $\left(h_{a b}\right)$, (b) chroma $\left(C^{*}{ }_{a b}\right)$ and (c) lightness $\left(L^{*}\right)$ in peach progenies of the Peach Breeding Program at Embrapa Temperate Agriculture in the 2015-2016 and 2016-2017

cycles, Pelotas, Rio Grande do Sul, Brazil

$\mathrm{H}^{2}$ estimate for $C^{*}{ }_{a b}$ was $43.36 \%$ and $70.21 \%$ for $L^{*}$ among all the progenies evaluated, when the two parents were yellow-flesh. The $\mathrm{h}^{2}$ for these parameters was estimated as $34.98 \%$ for $C^{*}{ }_{a b}$ (Figure $2 \mathrm{~b}$ ) and $60.51 \%$ for $L^{*}$ (Figure 2c).

$\mathrm{H}^{2}$ can be considered high for both $h_{a b}$ and $L^{*}$ and medium for $C^{*}{ }_{a b}$. However, this estimate has little use for breeding programs, where $\mathrm{h}^{2}$ has major importance. Selection effect depends on the magnitude of the additive genetic variance and not on the total genetic variance. Thus, heritability in the narrow-sense is a relevant factor when predicting the response of selection (Griffiths et al., 2015). The estimated $\mathrm{h}^{2}$ for $h_{a b}$ and $L^{*}$ parameters were medium $\left(60.41 \%\right.$ and $60.51 \%$, respectively), and medium to low for $C^{*}{ }_{a b}(34.98 \%)$, indicating that the parameters concerning the color shade of flesh are fairly easy transmitted. Therefore, with these results, it can be concluded that the selection of the parents based on the phenotype can be effective, where a medium genetic advance for the color shade character of peaches flesh is expected (Allard, 1960; Falconer \& Mackay, 2001).

Based on the results obtained from the 16 progenies and the color perception (Table 3), fruits were classified according to the shades of yellow and white-flesh, and the limits of these classes were defined according to $h_{a b}$ value (Table 4).

Table 3. Means of Hue angle $\left(h_{a b}\right)$, chroma $\left(C^{*}{ }_{a b}\right)$ and lightness $\left(L^{*}\right)$ characters in the 16 progenies of peach and their parents in the 2015-2016 and 2016-2017 cycles, in Embrapa Temperate Agriculture, Pelotas, Rio Grande do Sul, Brazil

\begin{tabular}{llllll}
\hline $\mathrm{F}_{1}$ progenies & $h_{a b}$ & Yellow-flesh color shade * & $C^{*}{ }_{a b}$ & $L^{*}$ & White-flesh color shade ** \\
\hline 2008.159 & 82.51 & yellow-orange & 56.81 & 69.86 & \\
2009.38 & 82.96 & yellow-orange & 53.32 & 68.22 & \\
2012.26 & 98.33 & & 21.41 & 76.35 & white \\
2012.43 & 97.65 & & 21.19 & 75.32 & white \\
2012.49 & 85.81 & yellow & 54.02 & 71.14 & \\
2012.61 & 82.29 & yellow & 55.46 & 70.17 & \\
2012.52 & 87.35 & ligth-yellow & 53.91 & 71.00 & \\
2012.66 & 85.62 & yellow & 53.25 & 70.15 & \\
2012.68 & 82.43 & yellow & 55.15 & 69.84 & \\
2012.88 & 84.48 & yellow-orange & 53.59 & 72.04 & \\
2012.31 & 99.46 & & 18.49 & 74.25 & white \\
2012.46 & 102.19 & & 22.79 & 75.40 & white with red spots \\
2012.99 & 93.80 & & 20.83 & 72.34 & white-green \\
2012.107 & 88.57 & yellow & 52.06 & 67.74 & \\
2012.111 & 88.64 & yellow & 51.87 & 67.34 & \\
2012.114 & 91.30 & ligth-yellow & 52.82 & 74.01 & \\
\hline
\end{tabular}




\begin{tabular}{llllll}
\hline Parents & \multicolumn{5}{c}{} \\
\hline Conserva 1526 & 84.00 & yellow-orange & 57.72 & 72.39 & \\
'Cerrito' & 80.12 & yellow-orange & 56.62 & 67.50 & \\
Cascata 1055 & 100.03 & & 22.22 & 78.90 & white with red spots \\
'Chimarrita' & 103.30 & & 19.62 & 74.09 & white with red spots \\
Conserva 672 & 83.96 & yellow-orange & 56.00 & 72.51 & \\
Conserva 947 & 86.11 & yellow & 56.09 & 71.97 & \\
Conserva 1600 & 79.72 & orange & 57.05 & 69.38 & \\
Conserva 1662 & 79.03 & orange & 58.90 & 68.99 & \\
'Maciel' & 83.55 & yellow-orange & 57.67 & 71.79 & \\
Cascata 1359 & 88.81 & yellow & 55.65 & 71.08 & \\
Cascata 1577 & 103.72 & & 16.68 & 77.02 & white-cream \\
'Chorão' & 103.71 & & 22.55 & 76.33 & white with red spots \\
Necta 506 & 89.86 & yellow & 53.69 & 71.12 & \\
'Sunmist' & 99.13 & & 25.79 & 73.91 & white \\
Necta 532 & 90.06 & ligth-yellow & 53.60 & 72.04 & \\
Necta 480 & 82.46 & yellow-orange & 53.36 & 65.87 & \\
Necta 540 & 93.77 & ligth-yellow & 54.16 & 71.18 & \\
'Morena' & 88.56 & yellow & 48.87 & 67.14 & \\
'Rubimel' & 90.22 & ligth-yellow & 52.82 & 72.14 & \\
TX2D163 & 96.50 & greenish-yellow & 48.67 & 76.95 & \\
\hline
\end{tabular}

Note. CIELAB color measurement system, Minolta CR-300 electronic colorimeter, D65 light source, $8 \mathrm{~mm}$. * orange $\left(h_{a b} \leq 80\right)$; yellow-orange $\left(80>h_{a b} \leq 85\right)$; yellow $\left(85>h_{a b} \leq 90\right)$; ligth-yellow $\left(90>h_{a b} \leq 95\right)$; greenish-yellow $\left(h_{a b}>95\right) . * *$ white-green $\left(h_{a b} \leq 95\right)$; white $\left(95>h_{a b} \leq 100\right)$; white-cream or white with red spots $\left(\mathrm{h}_{\mathrm{ab}}>100\right)$.

Table 4. Color shade defined based on Hue angle $\left(h_{a b}\right)$, chroma $\left(C^{*}{ }_{a b}\right)$ and lightness $\left(L^{*}\right)$

\begin{tabular}{|c|c|c|c|c|c|c|c|}
\hline \multicolumn{4}{|c|}{ Yellow-flesh } & \multicolumn{4}{|c|}{ White-flesh } \\
\hline Color shade & $h_{a b}$ & $C^{*}{ }_{a b}$ & $L^{*}$ & Color shade & $h_{a b}$ & $C_{a b}^{*}$ & $L^{*}$ \\
\hline Orange & $\leq 80$ & $\geq 57$ & $\geq 68$ & White-green & $\leq 95$ & $\geq 20$ & $\leq 73$ \\
\hline Yellow-orange & 80 to 85 & 53 to 58 & 65 to 73 & White & 95 to 100 & 18 to 22 & 73 to 76 \\
\hline Yellow & 85 to 90 & 51 to 57 & 67 to 73 & White-cream or & $>100$ & 16 to 23 & $>74$ \\
\hline Ligth-yellow & 90 to 95 & 50 to 55 & 71 to 75 & white with red spots & & & \\
\hline Greenish-yellow & $>95$ & $<50$ & $>75$ & & & & \\
\hline
\end{tabular}

In the case of yellow-flesh progenies, histograms were constructed, using the relative frequency distributions of individuals by class (Figure 3). In Figures $3 a$ to $3 k$, the distribution of the individuals of the four $F_{1}$ progenies with their respective $F_{1}$ reciprocal progenies was compared. Thus, it was possible to observe if there were differences when using a parent as a female or male (pollen). 

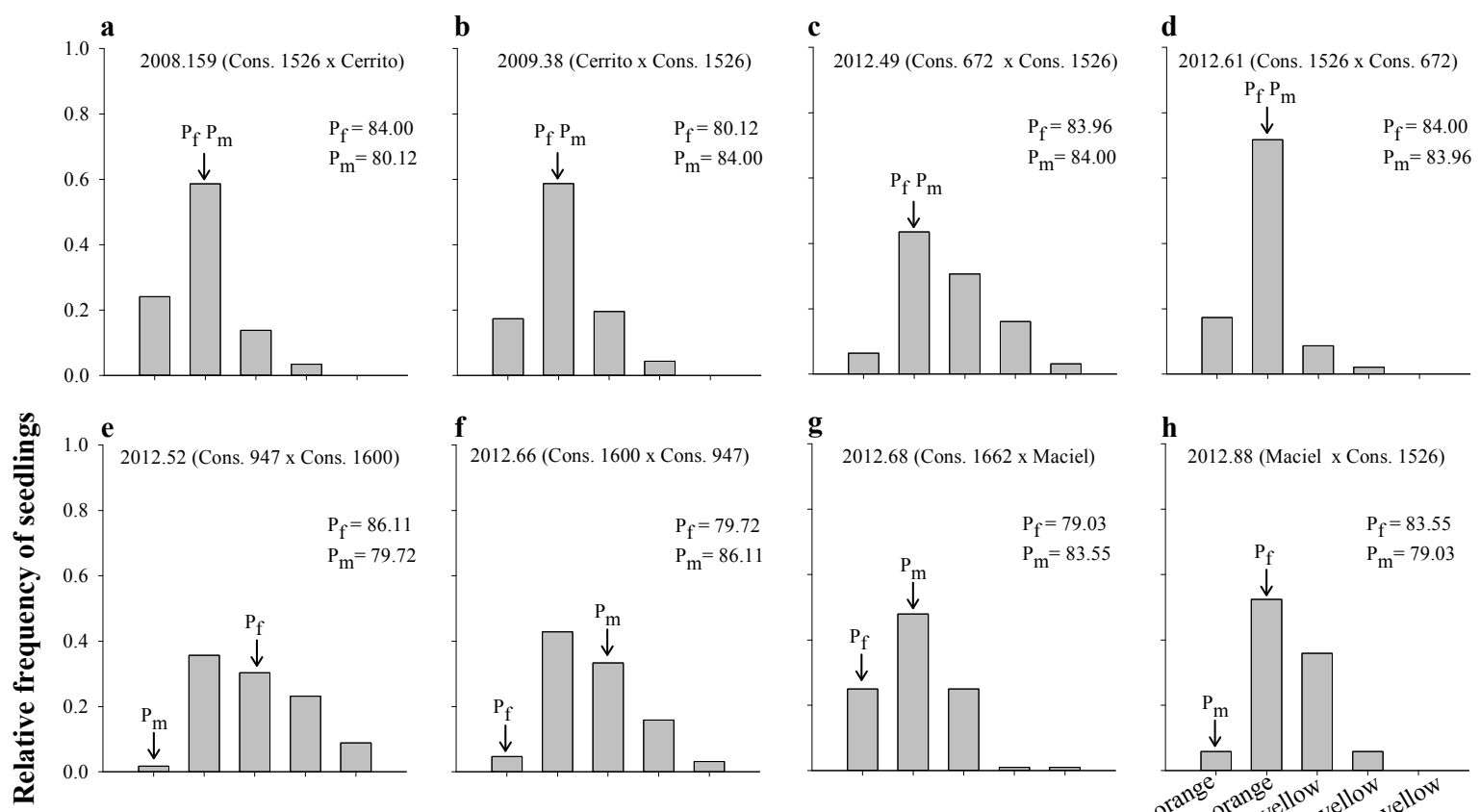

g
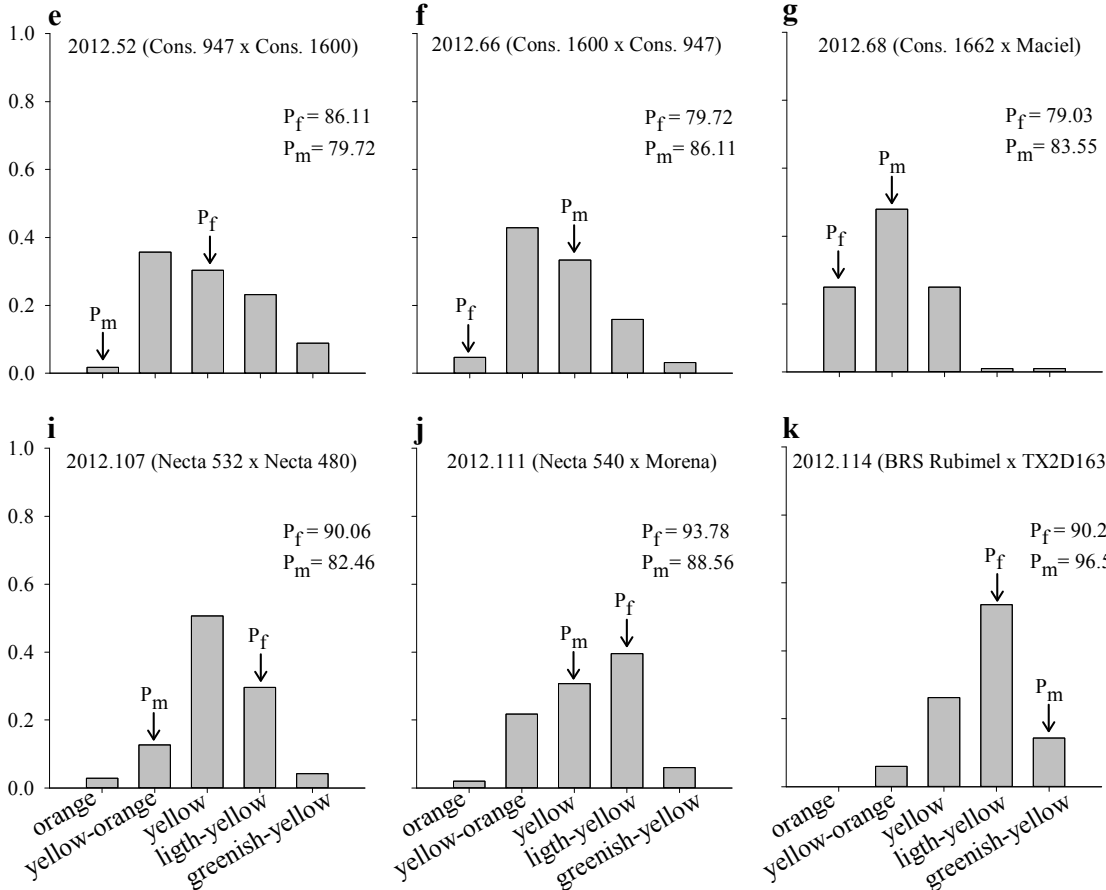

$\mathbf{k}$
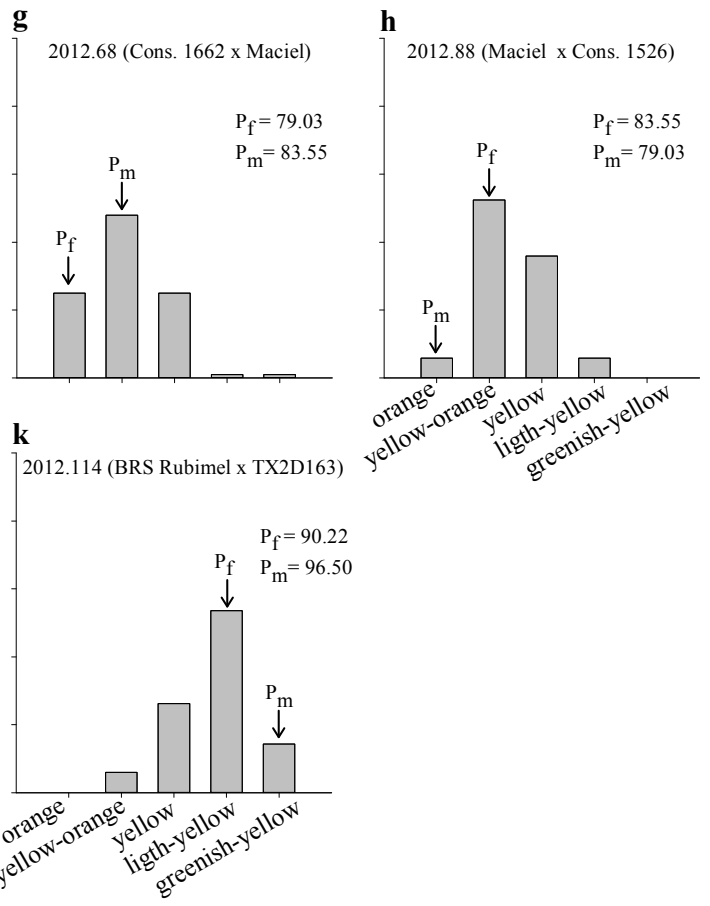

Color shade of peach flesh

Figure 3. Relative frequency distribution histograms for the color shade character of peach flesh, classified according to Hue angle $\left(h_{a b}\right)$ value (Table 4), in yellow-flesh peach progenies in the 2015-2016 and 2016-2017 cycles, in Embrapa Temperate Agriculture, Pelotas, Rio Grande do Sul, Brazil. The $h_{a b}$ mean value of the female parent is represented by $\mathrm{P}_{\mathrm{f}}$ and the male parent by $\mathrm{P}_{\mathrm{m}}$; Cons. = "Conserva"; Casc. = "Cascata"

The existence of transgressive segregation was generally verified; in another words, there were individuals with higher $h_{a b}$ values than any of the parents. This trend was also reported by Corrêa (2007), who worked with yellow-flesh peach progenies and used $h_{a b}$ for the analysis.

In the histograms, a differentiated behavior was not evident when using a genotype as female or male parent, in the case of reciprocal progenies (Figures $3 \mathrm{a} v s .3 \mathrm{~b}, 3 \mathrm{c} v s .3 \mathrm{~d}, 3 \mathrm{e} v s .3 \mathrm{f}$ and $3 \mathrm{~g} v s$. 3h). With the exception of Figures $3 \mathrm{~g}$ and $3 \mathrm{~h}$, the distribution in the graphs has the same tendency. It seems to be more concentrated in the class or near the class of the darkest parent, regardless of whether it is female or male parent. Deviations may be associated with the presence of some other genes (other than the $Y / y$ gene) with a minor effect, which are controlling the color shade. This result is in disagreement with Corrêa (2007), who observed a higher concentration of individuals with flesh tonality similar to the female parent, suggesting a maternal effect for this character.

Through the $t$-test, the hypothesis of maternal effect in the five studied reciprocal crosses was tested. In all cases, the $\mathrm{F}_{1}$ progeny versus their $\mathrm{F}_{1}$ reciprocal progeny (Londero et al., 2009), for the studied parameters $\left(h_{a b}, C^{*}{ }_{a b}\right.$ and $\left.L^{*}\right)$ was not significant by the $t$-test $(p>0.05)$. That is, there were no significant differences between the reciprocal progenies, indicating that there is no maternal effect on the transmission of this feature.

Flesh color shade is a complex character to analyze, and it is most correct to consider the three parameters $\left(h_{a b}\right.$, $C^{*}{ }_{a b}$ and $L^{*}$ ) together. In this way, a principal components analysis was also performed, with the three 
parameters. Tourjee et al. (1998) had already reported the importance of this analysis in the genotype classification according to their flesh color shade. This type of analysis is one of the pioneer methods of multivariate analysis, allowing to condense the matrix of correlations between the variables into a "principal components" of the total variability of the experiment. Thus, it allows to transform a set of intercorrelated variables into another set of uncorrelated variables that are the factors. These factors are a linear combination of the original variables. The first component (PC 1) better summarizes the information obtained and the second component (PC 2) summarizes the remaining information (Bisquerra, 1989).

The analyzed variables must be sufficiently correlated between them to justify the factorization of the correlation coefficient matrix, and, thus, justify the principal components analysis (Carmona, 2014; Varella, 2008). The three parameters studied for the flesh color shade $\left(h_{a b}, C^{*}{ }_{a b}\right.$ and $\left.L^{*}\right)$ had highly significant correlations $(p<$ $0.0001)$.

The importance of a principal component is assessed by the ratio of the total variance explained by the component (Cruz \& Carneiro, 2012; Varella, 2008). The cumulative proportion of the total variance between the first two principal components was $96.6 \%$. According to Cruz and Carneiro (2012), for applications in several areas and in studies of genetic divergence, the number of principal components used has been those that accumulate $80 \%$ or more of the proportion of total variance. The first two principal components were used, which mean good approximation in a two-dimensional (bi-plot) representation (Figure 4).

Table 5 shows the eigenvectors values and the correlation matrix of the first two principal components with the original variables. The cophenetic correlation coefficient was 0.988 , indicating a low degree of distortion between the original data and the graphical representation (Cruz \& Carneiro, 2012; Varella, 2008).

Table 5. Relative Eigenvectors and correlations of the principal components (PC) with the original variables: Hue angle $\left(h_{a b}\right)$, chroma $\left(C^{*}{ }_{a b}\right)$ and lightness $\left(L^{*}\right)$

\begin{tabular}{llllll}
\hline & \multicolumn{2}{c}{ Eigenvectors } & & \multicolumn{2}{c}{ Correlations with the original variables* } \\
\cline { 2 - 3 } \cline { 5 - 6 } & $\mathrm{e} 1$ & $\mathrm{e} 2$ & & PC 1 & PC 2 \\
\hline$h_{a b}$ & 0.60 & -0.27 & & 0.96 & -0.16 \\
$C^{*}{ }_{a b}$ & -0.58 & 0.50 & & -0.94 & 0.29 \\
$L^{*}$ & 0.55 & 0.82 & & 0.88 & 0.48 \\
\hline
\end{tabular}

Note. ${ }^{*}$ Cophenetic correlation coefficient $(\mathrm{CCC})=0.998$.

The principal components are "artificial" variables that were obtained by linear combination of the three considered parameters. Each of the parents and the progenies take values that were projected on the graph (Figure 4), and its interpretation is based on the most correlated parameters (Cruz \& Carneiro, 2012; Varella, 2008). Consequently, the first principal component (PC 1) combines $h_{a b}$ and $L^{*}$, showing very high positive correlations of 0.96 and 0.88 , respectively. Thereby, PC 1 on the abscissa $(x)$ axis, separates the parents and the progenies that have higher values for these parameters from those that have low ones. It was ordered from left to right, those with the lowest to the highest $h_{a b}$, for example, from orange and yellow-orange to light-yellow and greenish-yellow (Figure 4). This PC 1 also separates those that presented lower to higher $L^{*}$, from the darker colors to the clearer ones. In addition, PC 1 is strongly correlated with $C^{*}{ }_{a b}$, but in a negative way (-0.94), ordering from left to right those that presented the highest to the lowest $C^{*}{ }_{a b}$, for example, from the sharper colors to the less saturated colors. 


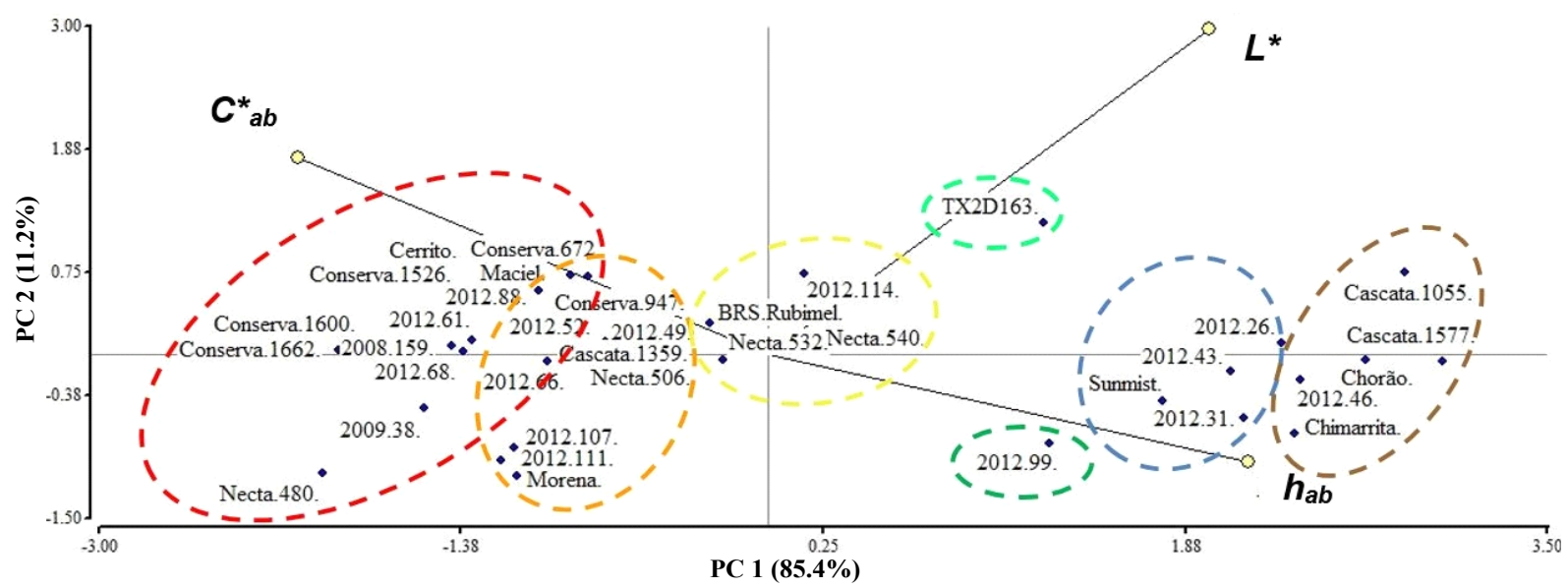

Figure 4. Principal component (PC) analysis, with Hue angle $\left(h_{a b}\right)$, chroma $\left(C^{*}{ }_{a b}\right)$ and lightness $\left(L^{*}\right)$, showing the categories defined for yellow-flesh and white-flesh fruits (Table 4) in the 2015-2016 and 2016-2017 cycles, in Embrapa Temperate Agriculture, Pelotas, Rio Grande do Sul, Brazil. Averages of the progenies and the parents obtained in the two cycles were used

The second axis $(y)$ corresponds to PC 2 and is moderately correlated with $C^{*}{ }_{a b}$ and $L^{*}$, positive correlations of 0.29 and 0.48 , respectively. It was ordered from the bottom to the top, those that present higher to lower values for these parameters.

The color categories previously defined with the $h_{a b}$ values, for fruits of yellow-flesh are represented with circles (Figure 4). In the red circle are grouped the progenies and parents of orange and yellow-orange flesh color $\left(h_{a b}<\right.$ $85)$, in the orange circle the yellow-flesh color $\left(85 \geq h_{a b}<90\right)$, in the yellow circle the light-yellow flesh color $\left(90 \geq h_{a b}<95\right)$, and in the light-green circle the greenish-yellow flesh color $\left(h_{a b}>95\right)$ (Figure 4$)$.

It is observed that the categories previously defined agreed with the identified groups by the principal components graph (Tables 3 and 4). All cultivars, selections and progenies of yellow-flesh follow the direction of the $h_{a b}$ axis. The orange, yellow-orange, and yellow shades were located in the left quadrants of the graph, those with light-yellow in the center, and those with greenish-yellow in the upper right quadrant.

Conserva 1600 and Conserva 1662 parents were grouped on the extreme left of the chart in the upper left quadrant (Figure 4). These two selections were the only ones classified with orange color shade of flesh, and $h_{a b}$ values below $80^{\circ}\left(79.72^{\circ}\right.$ and $79.03^{\circ}$, respectively).

The 2012.66 and 2012.88 progenies are at the limit of the groups between color shades of yellow-orange and yellow flesh (Figure 4), with average values of $85.62^{\circ}$ and $84.48^{\circ}$, respectively, being within the limit defined for these two categories. The same can be observed for the parents 'BRS Rubimel', Necta 506 and Necta 532, but between yellow and light-yellow flesh color shade, with mean values of $90.22^{\circ}, 89.86^{\circ}$ and $90.06^{\circ}$, respectively (Table 3).

Furthermore, in Figure 4 the categories defined above for white-flesh fruits are circled. In the brown circle, progenies and parents of white-cream or white with presence of red spots are grouped $\left(h_{a b}>100\right)$; in the blue circle, the ones with white-flesh color $\left(95>h_{a b} \leq 100\right)$, and in the dark-green circle, the white-green flesh $\left(h_{a b} \leq\right.$ 95).

The 2012.99 progeny had seedlings classified with white-greenish flesh, located on the left of lower right quadrant (Figure 4). The shades white and white-cream or white with red spots are located on the right of the right quadrants (lower and upper). Within this last group the parents 'Chimarrita', 'Chorão' and Cascata 1055, and 2012.46 progeny present white-flesh with red spots distributed in the flesh, mainly near the stone, and Cascata 1577 parent has a white-cream flesh with some reddish coloration only near the stone.

Measuring the color shade of flesh in canning peaches, fresh and processed, Tourjee et al. (1998) performed the principal components analysis directly with the coordinates obtained by the colorimeter $\left(L^{*}, a^{*}\right.$ and $\left.b^{*}\right)$. They differentiated three groups of fruit color according to the content of carotenoids that they had, emphasizing the importance of studying these complex characters with multivariate analysis techniques. 


\section{Conclusions}

Heritability of color shade parameters (Hue angle, chroma and lightness) is medium in peaches.

Hue angle is the correct parameter to be used to classify and study the color shade of yellow-flesh peaches and nectarine fruits.

No maternal effect was found in the transmission of the character of flesh color shade.

Principal component analysis is an option for this study involving complex characters, such as the flesh color shade.

\section{References}

Allard, R. W. (Ed.). (1960). Principles of plant breeding (1st ed.). New York: John Wiley \& Sons, Inc.

Adami, M., Franceschi, P., Brandi, F., Liverani, A., Giovannini, D., Rosati, C., ... Tartarini, S. (2013). Identifying a carotenoid cleavage dioxygenase $(c c d 4)$ gene controlling yellow/white fruit flesh color of peach. Plant Molecular Biology Reporter, 31(5), 1166-1175. https://doi.org/10.1007/s11105-013-0628-6

Adriano, E., Leonel, S., \& Evangelista, R. M. (2011). Fruit quality of barbados cherry trees cv. Olivier in two stages of maturity. Revista Brasileira de Fruticultura, 33(SP 1), 541-545. https://doi.org/10.1590/ S0100-29452011000500073

Bassi, D., \& Monet, R. (2008). Botany and Taxonomy. In D. R. Layne, \& D. Bassi (Eds.), The peach: Botany, production and uses (pp. 1-36). Wallingford: CAB International. https://doi.org/10.1079/97818459338 69.0001

Bible, B. B., \& Singha, S. (1993). Canopy position influences CIEALAB coordinates of peach color. HortScience, 28(10), 992-993. https://doi.org/10.21273/HORTSCI.28.10.992

Bisquerra, R. A. (1989). Introducción al análisis multivariable. Un enfoque informático con los paquetes SPSS-X, BMDP, LISREL y SPAD (v. 1). Barcelona: PPU, S.A.

Byrne, D. H., Nikolic, A. N. \& Burns, E. E. (1991). Variability in sugars, acids, firmness, and color characteristics of 12 peach genotypes. Journal of the American Society for Horticultural Science, 116(6), 1004-1006. https://doi.org/10.21273/JASHS.116.6.1004

Byrne, D. H., Raseira, M. B., Bassi, D., Piagnani, M. C., Gasic, K., Reighard, G. L., .. Pérez, S. P. (2012). In M. L. Badenes, \& D. H. Byrne (Eds.), Fruit breeding (pp. 505-569). New York: Springer. https://doi.org/ 10.1007/978-1-4419-0763-9_14

Carmona, F. (2014). Un ejemplo de ACP paso a paso. Barcelona: Departament d'Estadística, Universitat de Barcelona. Retrieved from http://www.ub.edu/stat/docencia/Mates/ejemploACP.PDF

Castro, L. A. S., \& Barbieri, R. L. (2014). Botânica e morfologia do pessegueiro. In M. C. B. Raseira, J. F. M. Pereira, \& F. L. C. Carvalho (Eds.), Pessegueiro (pp. 25-43). Brasília, DF: Embrapa.

Chitarra, M. I. F., \& Chitarra, A. B. (Eds.). (2005). Pós-colheita de frutas e hortaliças: Fisiologia e manuseio (2nd ed.). Lavras, MG: UFLA.

CIE. (2007). Colorimetry - Part 4: CIE $1976 L^{*} a * b *$ colour space. Vienna: CIE Central Bureau. Retrieved from http://www.unife.it/scienze/astro-fisica/insegnamenti/ottica-applicata/materiale-didattico/colorimetria/CIE\% 20DS\%20014-4.3.pdf

Connors, C. H. (1920). Some notes on the inheritance of unit characters in peach. Proceedings of the American Society for Horticultural Science, 16, 24-36.

Corrêa, E. R. (2007). Estudo da herdabilidade de alguns carácteres em pessegueiro: Ciclo, tonalidade da cor da polpa e compostos fenólicos (Dissertation (MSc), Faculty of Agronomy Eliseu Maciel, Federal University of Pelotas, Pelotas, Rio Grande do Sul, Brazil).

Cruz, C. D., \& Carneiro, P. C. S. (Eds.) (2012). Modelos biométricos aplicados ao melhoramento genético. Viçosa, MG: Editora UFV.

Falconer, D. S., \& Mackay, T. F. C. (Eds.). (2001). Introducción a la genética cuantitativa (Spanish Ed.). Zaragosa: Acribia.

Gil, M. I., Tomás-Barberán, F. A., Hess-Pierce, B., \& Kader, A. A. (2002). Antioxidant capacities, phenolic compounds, carotenoids, and vitamin $\mathrm{C}$ contents of nectarine, peach, and plum cultivars from California. Journal of Agricultural and Food Chemistry, 50(17), 4976-4982. https://doi.org/10.1021/jf020136b 
Griffiths, A. J. F., Wessler, S. R., Carroll, S. B., \& Doebley, J. (Eds.). (2015). Introduction to Genetical Analysis (11th ed.). New York: W. H. Freeman and Company.

Londero, P. M. G., Ribeiro, N. D., Cerutti, T., Mazeiro, S. M., Rosa, D. P., \& Rosa, S. S. (2009). Maternal effect in sulfur amino acids content expression in common bean grains. Ciência Rural, 39(6), 1884-1887. https://doi.org/10.1590/S0103-84782009005000129

Macevoy, B. (2005). Modern colors model. Handprint.com. Retrieved from https://www.handprint.com/ HP/WCL/color7.html.

Mayer, N. A., Mattiuz, B. \& Pereira, F. M. (2008). Postharvest peach quality of cultivars and selections produced in Jaboticabal micro-region, São Paulo state, Brazil. Revista Brasileira de Fruticultura, 30(3), 616-621. https://doi.org/10.1590/S0100-29452008000300009

Raseira, M. C. B., \& Franzon, R. C. (2014). Melhoramento genético. In M. C. B. Raseira, J. F. M. Pereira, \& F. L. C. Carvalho (Eds.), Pessegueiro (pp. 67-72). Brasília, DF: Embrapa.

Raseira, M. C. B., Pereira, J. F. M., \& Carvalho F. L. C. (Eds.). (2014). Pessegueiro (1st ed.). Brasília, DF: Embrapa.

Silva, J. O. C. (2013). Seleção em progênies S1 e S2 de pessegueiro via modelos mistos (REML/BLUP) (Thesis PhD, Federal University of Viçosa, Viçosa, MG, Brazil).

Tourjee, K. R., Barrett, D. M., Romero, M. V. \& Gradziel, T. M. (1998). Measuring flesh color variability among processing clingstone peach genotypes differing in carotenoid composition. Journal of the American Society for Horticultural Science, 123(3), 433-437. https://doi.org/10.21273/JASHS.123.3.433

Trevisan, R., Gonçalves, E. D., \& Coutinho, E. F. (2004). Peach quality of conventional and integrated production orchards. Ciência Rural, 34(6), 1747-1751. https://doi.org/10.1590/S0103-84782004000600012

Varella, C. A. A. (2008). Análise multivariada aplicada as ciências agrárias: Análise de componentes principais. Universidade Federal Rural do Rio de Janeiro, Pós-Graduação em Agronomia, Seropédica-RJ. Retrieved from http://www.ufrrj.br/institutos/it/deng/varella

Vizzotto, M., Cisneros-Zevallos, L., Byrne, D., Okie, W., \& Ramming, D. (2006). Total phenolic, carotenoids, and anthocyanin content and antioxidant activity of peach and plum genotypes. Acta Horticulturae, 713, 453-455. https://doi.org/10.17660/ActaHortic.2006.713.67

Voss, D. H. (1992). Relating colorimeter measurement of plant color of the Royal Horticultural Society colour chart. HortScience, 27(12), 1256-1260. https://doi.org/10.21273/HORTSCI.27.12.1256

Wagner Júnior, A. (2003). Avaliação de germoplasma de pessegueiro, quanto à reação à Monilinia fructicola (Wint.) Honey (Dissertation (MSc), Faculty of Agronomy Eliseu Maciel, Federal University of Pelotas, Pelotas, Rio Grande do Sul, Brazil).

Werner, D., Creller, M., \& Chaparro, J. (1998). Inheritance of the blood-flesh trait in peach. HortScience, 33(7), 1243-1246. https://doi.org/10.21273/HORTSCI.33.7.1243

Williamson, J. D., Peace, C. P., Bliss, F. A., Garner, D. T., \& Crisosto, C. H. (2006). Evidence for a single locus controlling flesh color, senescent leaf color, and hypanthium color in peach. Journal of the American Society for Horticultural Science, 131(2), 256-260. https://doi.org/10.21273/JASHS.131.2.256

\section{Copyrights}

Copyright for this article is retained by the author(s), with first publication rights granted to the journal.

This is an open-access article distributed under the terms and conditions of the Creative Commons Attribution license (http://creativecommons.org/licenses/by/4.0/). 